\title{
Effects of feed restriction on yield, retail cuts and tissue composition of carcass of Saanen kids ${ }^{1}$
}

\section{Enrique Alejandro Yáñez ${ }^{2}$, Kleber Tomás de Resende ${ }^{3}$, Ângela Cristina Dias Ferreira ${ }^{4}$, Ariosvaldo Nunes de Medeiros ${ }^{5}$, Américo Garcia da Silva Sobrinho ${ }^{3}$, Silvana Martinez Beraldi Artoni ${ }^{6}$}

\footnotetext{
1 Parte da tese de Doutorado do primeiro autor. Projeto financiado pela FAPESP.

2 Departamento de Producción Animal, Facultad de Ciencias Veterinarias, UNNE, Corrientes. Sargento Cabral 2139 , Corrientes, Argentina. CP: 3400 .

${ }^{3}$ Departamento de Zootecnia, Faculdade de Ciências Agrárias e Veterinárias, Unesp, Jaboticabal. Rod. P.D. Castellane Km 5, Jaboticabal, SP, Brasil CEP: 14884-900.

${ }^{4}$ Departamento de Zootecnia, Unoeste-Presidente Prudente, SP, Brasil.

${ }^{5}$ Departamento de Zootecnia do Centro de Ciências Agrárias, UFPB, Areia, PB, Brasil.

6 Departamento de Morfologia e Fisiologia Animal, FCAV, Unesp, Jaboticabal, SP, Brasil.
}

ABSTRACT - Twenty-seven male Saanen kids were used in a completely randomized design to investigate the effect of feed restriction on retail and biological carcass yields, proportion of carcass retail cuts, carcass compactness, leg tissue composition, and ribeye area (REA). Animals were assigned to one of the following treatments: 0 (free access to feed: $a d$ libitum), 30 or $60 \%$ of feed restriction. Initial body weight (BW) averaged $5 \mathrm{~kg}$ and animals were slaughtered when they reached $20 \mathrm{~kg} \mathrm{BW}$. Data were submitted to regression analysis as function of feed restriction. Feed restriction reduced carcass weight, retail cuts weight, and chump proportion and increased neck proportion. Bone proportion also increased while muscle tissue and fat proportion (including subcutaneous fat) decreased with feed restriction. Although REA and carcass compactness were both affected by feed restriction, they can be used to predict the proportion of carcass muscle. Carcass traits of Saanen kids were not negatively affected by $30 \%$ of feed restriction.

Key Words: bone, retail yield, intermuscular fat, muscle, subcutaneous fat

\section{Efeito da restrição alimentar sobre o rendimento dos cortes comerciais e a composição tecidual da carcaça de cabritos Saanen}

RESUMO - Com o objetivo de estudar o efeito da restrição alimentar sobre as características de carcaça de caprinos leiteiros, realizou-se um experimento utilizando 27 cabritos machos Saanen distribuídos nos tratamentos 0 (alimentação à vontade), 30 ou $60 \%$ de restrição. Os animais apresentavam $5 \mathrm{~kg}$ de PV inicial e foram abatidos quando atingiram $20 \mathrm{~kg}$ de PV. Foram avaliados os rendimentos comercial e biológico, os cortes comerciais, a composição tecidual da perna, a área de olho-de-lombo (AOL) e a compacidade da carcaça. Utilizaram-se o delineamento inteiramente ao acaso e a análise de regressão em função da restrição alimentar. A restrição alimentar provocou redução do peso da carcaça e dos cortes comerciais, aumento da proporção do pescoço e diminuição da proporção do lombo. A proporção de ossos aumentou e a do tecido muscular e da gordura total diminuiu com o aumento da restrição. A proporção de gordura subcutânea diminuiu com o aumento da restrição alimentar. A área de olho-de-lombo (AOL) e a compacidade da carcaça foram afetadas pela restrição alimentar, mas ambas as medidas podem ser utilizadas para predizer a proporção de músculo da carcaça. O tratamento com $30 \%$ de restrição alimentar não prejudica a qualidade da carcaça de cabritos leiteiros.

Palavras-chave: gordura subcutânea, gordura intermuscular, músculo, ossos, rendimento comercial

\section{Introduction}

Brazil has approximately $9,350,000$ goats, $90 \%$ of them in the Northeast region (IBGE, 2000), where the system of extensive pasture predominates, characterized by a low technological level. In contrast, in the surroundings of medium-size and large towns, especially those located in the Southeast region of the country, intensive system of dairy goats has been increasing, with emphasis on Saanen and Alpine animals.

Brazilian research on dairy goats has been recently advancing in order to improve the efficiency of production systems, with productivity that would make the activity economically viable. However, little has been done in 
terms of exploitation of dairy kids for slaughter, with breeders usually sacrificing male kids at birth because they consider their rearing not economically viable, or reducing feed availability in an attempt to reduce cost of production.

Because of the high prolificacy characteristic of the species, the number of male and female kids born in a dairy herd along the year may exceed the number destined to replacement with a consequent potential for meat production. This potential usually is not exploited by breeders, partially due to the lack of studies on goat meat production and also to the lack of exploration of the consumer market.

In Brazil there is no standard for the commercialization of goat carcasses or cuts. Carcasses are usually sold whole or as halves, with no difference in price for those with a greater proportion of choice cuts such as the leg, shoulder or loin, or with respect to conformation and finishing.

Goats are characterized by carcasses of low compactness, with little subcutaneous fat and with meat containing approximately $50 \%$ less fat than lamb or beef (Warmington \& Kirton, 1990; Madruga, 1999) As a consecuence, goat meat is thought to be a good alternative for those consumers who look for a healthy protein of high biological value. These characteristics of goat carcasses may be influenced by the type and level of kid nutrition. Tissue growth starts from bone, followed by muscle and adipose tissue (Lawrence \& Fowler, 1997), with an allometry coefficient of $<1,=1$ and $>1$, respectively. This indicates that animals fed ad libitum may normally develop all of their tissues, including fat, while tissue development will be affected in underfed animals, adipose tissue in particular and, depending on the extent of underfeeding, also muscle tissue.

The objective of breeders who reduce the quantity or quality of feed supplied to male kids is an economic one, since feeding is the most important item in the cost of production. However, the limit of feed restriction as to not impair carcass quality has not yet been established. Thus, the objective of the present study was to assess the effect of feed restriction on the yield, retail cuts and tissue composition of dairy kid carcasses.

\section{Material and Methods}

The experiment was conducted in the Goat Rearing Sector of the Faculty of Agrarian and Veterinary Sciences (FCAV), State of São Paulo University (Unesp), Jaboticabal, São Paulo, Brazil. Twenty-seven intact
Saanen kids averaging initial body (BW) of $5 \mathrm{~kg}$ at 14 days old were divided into nine groups of three animals, each assigned to one of three feeding levels in a complete randomized manner: $\mathrm{T}_{1}: 0 \%$ restriction (ad libitum); $\mathrm{T}_{2}: 30 \%$ restriction, or $\mathrm{T}_{3}: 60 \%$ restriction. When the animals fed ad libitum reached $20 \mathrm{~kg} \mathrm{BW}$, the corresponding group was slaughtered.

A maximum amount of cow milk of 1.50, 1.05 and $0.60 \mathrm{~L} /$ day was offered to $\mathrm{T}_{1}, \mathrm{~T}_{2}$ and $\mathrm{T}_{3}$, respectively, with all animals being weaned at 50 days of age. A solid diet was offered starting at 7 days of age at pre-established levels. Leftover feed was weighed and the amount supplied daily was adjusted for each feeding level, with 10 to $15 \%$ leftovers being permitted for the animals fed ad libitum.

The kids were housed individually in hanging cages and were dehorned at 10 days of life and weighed weekly. The animals of the three treatments received the same ration consisting of $46.9 \%$ corn plant hay and $53.1 \%$ concentrate (25.9\% ground corn, $19.3 \%$ soy bran, $4.3 \%$ sugar cane molasses, $2.0 \%$ mineral nucleus, $0.8 \%$ soy oil, and $0.8 \%$ limestone). The ration contained $16.5 \% \mathrm{CP}, 48.8 \% \mathrm{NDF}$ and 2.46 Mcal of ME/kg DM.

Corn plant hay was obtained by harvesting corn with a silage machine when the grain was on the dough stage. Then, it was dried in the sun for $72 \mathrm{~h}$, and ground in a knife mill with a $0.1-\mathrm{cm}$ mesh sieve and stored in nylon bags until the time for utilization.

When the animals reached slaughtering weight, they animals were deprived of feed for $24 \mathrm{~h}$ and water for $16 \mathrm{~h}$, and fasting live weight $(\mathrm{FW})$ was determined. The animals were killed with an electric shock followed by bleeding. The contents of the gastrointestinal tract (GIT), the urinary bladder and gall-bladder was removed to determine empty body weight (EBW).

After skinning and evisceration, the carcass was obtained by separation from the hooves through the carpalmetacarpal and tarsal-metatarsal joints and from the head through the atlanto-occipital joint. The kidneys, perirenal fat and the diaphragm were also removed and hot carcass weight $(\mathrm{HCW})$ was determined. The carcass was then placed in a chilled room $\left(4^{\circ} \mathrm{C}\right)$ for $24 \mathrm{~h}$ and chilled carcass weight (CCW) recorded. Internal carcass length (ICL) was also measured as the distance between the cranial margin of the pubis and the cranial margin of the first rib at its midpoint. This measurement was then used to calculate carcass compactness $(\mathrm{kg} / \mathrm{cm})$ as CCW/ICL.

The carcasses were cut longitudinally into two halves and the left half was sectioned into seven regions or retail cuts (Figure 1): 

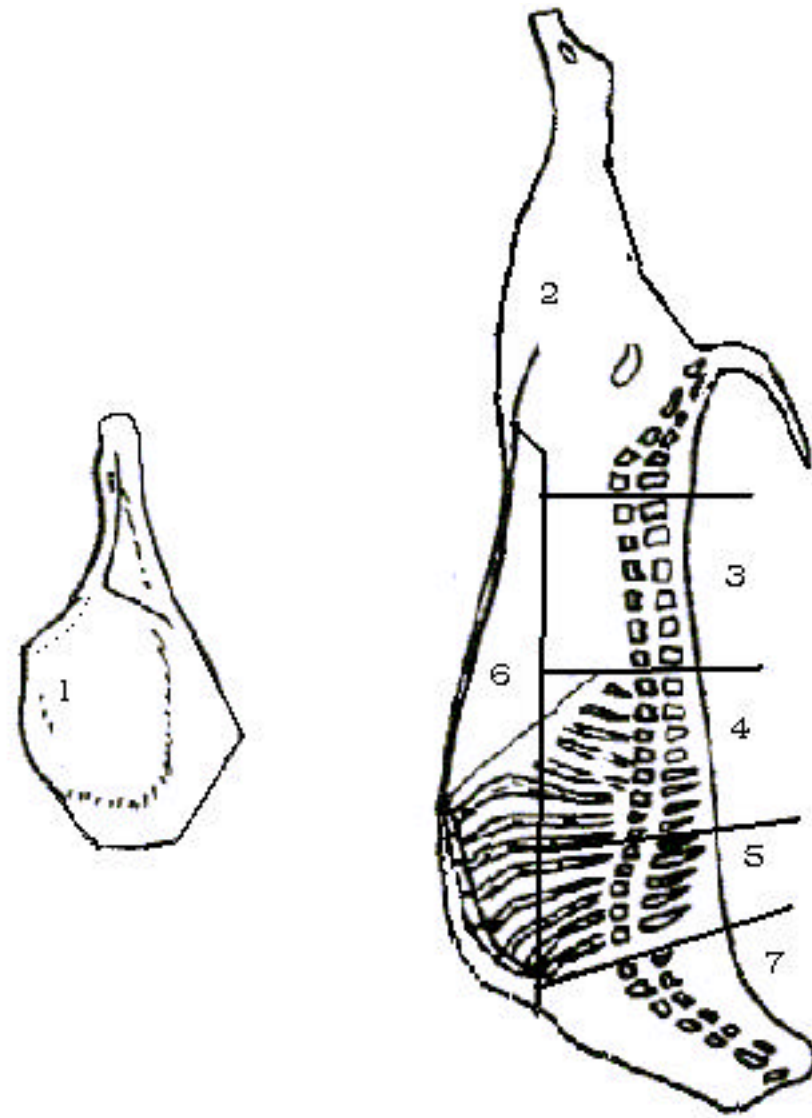

Figure 1 - Section point of retail cuts: 1. shoulder; 2. leg; 3. chump; 4. $6^{\text {th }}-13^{\text {th }} \mathrm{rib} ; 5.1^{\text {st }}-5^{\text {th }}$ rib; 6 . brisket; 7. neck.

- neck: region of the seven cervical vertebrae;

- shoulder: region including the shoulder blade, humerus, ulna, radius, and carpus;

- brisket: region having the lower half of the ribs and the sternum as the bone base, sectioned along a straight line from the cranial tip of the sternum to the intersection of the rectus abdominal muscle, internal oblique abdominal muscle and an imaginary vertical line starting from the lumbosacral joint;

$-1^{\text {st }}$ to $5^{\text {th }}$ rib: region with a bone base consisting of the first five thoracic vertebrae, together with the upper half of the corresponding ribs;

$-6^{\text {th }}$ to $13^{\text {th }}$ rib: region with a bone base consisting of the corresponding vertebrae and upper portion of the ribs;

- chump: region consisting of the lumbar vertebrae;

- leg: region with a bone base consisting of the sacral vertebrae and the first two coccygeal vertebrae, ilium, ischium, pubis, femur, tibia, and tarsus.

Commercial yield $(\%)=\mathrm{CCW} / \mathrm{FW}$ and biological yield $(\%)=\mathrm{HCW} / \mathrm{EBW}$ were determined. The ribeye area (REA), in $\mathrm{cm}^{2}$, was determined in the section between the $13^{\text {th }}$ thoracic vertebra and the $1^{\text {st }}$ lumbar vertebra according to the method of UNESP-GRID (Yáñez et al., 2005).

The left leg of each animal was frozen at $-20^{\circ} \mathrm{C}$ and then thawed for dissection and determination of tissue composition. The piece was trimmed by removing the tarsus and the distal end of the tibia by means of a cut proximal to the medial and lateral malleoli of the tibia and in the tuberosity of the heel. The tissues corresponding to the insertion of the abdominal muscles and the fat present in the region of the pelvic cavity (pelvic fat) were also removed. The legs were dissected into the following tissues:

- subcutaneous fat: surface or external surface fat;

- intermuscular fat: fat localized between the muscles;

- muscle: all the dissected muscle after removal of adhering intermuscular fat;

- bone: total weight of bones free of other tissues;

- others: tendons, fasciae, glands, nerves, and blood vessels.

Statistical analysis consisted of a fully randomized design with three treatments and nine replicates. The means were compared by Tukey test at 5\% level of significance and the different variables were submitted to regression analysis as a function of feed restriction using the Statistical Analysis System software (SAS, 1999).

\section{Results and Discussion}

The experimental period lasted 76 days and the animals were slaughtered, on average, at 90 days of age. Table 1 presents the data corresponding to the real restriction obtained during the experiment, the weight gain for each treatment, the proportional weight gain of restricted animals in relation to the animals fed ad libitum, and slaughtering BW. The real restriction obtained was calculated considering the ingestion of both milk and solid feed.

The use of three feeding levels was due to the need to obtain curves showing the biological behavior of the animals fed ad libitum or underfed which would permit the evaluation of different points representing the wide gamut of situations observed among breeders. The treatment $\mathrm{T}_{2}, 30 \%$ restriction, with a supply of $1 \mathrm{~L}$ milk/animal/day, was considered sufficient to satisfy the nutritional requirements of the animals up to weaning. In contrast, $\mathrm{T}_{3}, 60 \%$ restriction, was considered an extreme situation only applicable for experimental purposes.

The performance of animals submitted to restriction corresponded approximately to the proportional quantity of feed ingested. It is possible that the higher efficiency of milk utilization compared to solid feed permitted the maintenance of growth in these animals. 
Table 1 - Effects of feed restriction on daily weight gain, feed conversion, and slaughter liver weight in Saanen male kids

\begin{tabular}{|c|c|c|c|c|c|}
\hline \multirow[t]{2}{*}{ Treatment } & \multirow{2}{*}{$\begin{array}{c}\text { Actual restriction } \\
\left(\% \text { of } \mathrm{T}_{1}\right)\end{array}$} & \multicolumn{2}{|c|}{ Weight gain } & \multirow[t]{2}{*}{ Conversion ${ }^{1}$} & \multirow{2}{*}{$\begin{array}{l}\text { Live weight } \\
\qquad(\mathrm{kg})\end{array}$} \\
\hline & & g/day & $\left(\%\right.$ of $\left.\mathrm{T}_{1}\right)$ & & \\
\hline $0 \%$ restriction & - & 213.3 & - & 2.0 & 21.03 \\
\hline $30 \%$ restriction & 30.32 & 148.4 & 69.57 & 1.9 & 16.18 \\
\hline $60 \%$ restriction & 58.05 & 79.9 & 37,46 & 2.3 & 11.07 \\
\hline
\end{tabular}

${ }_{1}$ Conversion: calculated taken into account milk and solid feed, as $\mathrm{kg}$ dry matter ingested/live weight gain.

Table 2 - Means $( \pm$ sd) for fasting weight $(F W)$, empty body weight (EBW), hot carcass weight (HCW), cooled carcass weight (CCW), biological and retail carcass yields of feed-restricted kids

\begin{tabular}{lccccc}
\hline Treatment & FW $(\mathrm{kg})$ & EBW $(\mathrm{kg})$ & HCW $(\mathrm{kg})$ & Biological yield $(\%)^{1}$ & $\mathrm{CCW}(\mathrm{kg})$ \\
\hline $0 \%$ restriction & $19.8 \pm 0.51 \mathrm{a}$ & $16.7 \pm 0.61 \mathrm{a}$ & $9.0 \pm 0.51 \mathrm{a}$ & $53.8 \pm 1.88 \mathrm{a}$ & $8.7 \pm 0.54 \mathrm{a}$ \\
$30 \%$ restriction & $15.6 \pm 1.17 \mathrm{~b}$ & $12.9 \pm 0.98 \mathrm{~b}$ & $7.0 \pm 0.61 \mathrm{~b}$ & $43.7 \pm 2.41 \mathrm{a}$ \\
$60 \%$ restriction & $10.6 \pm 0.96 \mathrm{c}$ & $8.7 \pm 0.69 \mathrm{c}$ & $4.6 \pm 0.33 \mathrm{c}$ & $54.3 \pm 1.88 \mathrm{a}$ & $53.2 \pm 1.66 \mathrm{a}$ \\
\hline
\end{tabular}

a,b,c Means within column with common superscript do not differ $(P>0.05)$.

1 Biological yield = hot carcass weight/empty body weight $(\mathrm{HCW} / \mathrm{EBW})$.

2 Retail yield $=$ cooled carcass weight/fasting weight $(\mathrm{CCW} / \mathrm{FW})$.

Table 2 presents carcass weight, commercial and biological yields. Carcass dressing out is an important parameter, at times the only one used for commercialization. Thus, we opted for commercial yield, the most representative for slaughterhouses, which fast the animals and obtain carcass weight after cooling. In contrast, biological yield, by eliminating the variations influenced by gastrointestinal content, represents more faithfully the development of the different parts that compose live weight. This parameter, however, is impracticable in the daily routine of breeders and meat packing plants, and its use is limited to research.

The variables FW, EBW, HCW and CCW differed between treatments $(\mathrm{P}<0.05)$. Biological yield and commercial yield did not differ $(\mathrm{P}>0.05)$ between $\mathrm{T}_{1}$ and $\mathrm{T}_{2}$. Dressing out data permitted us to infer that $\mathrm{T}_{3}$ animals presented a proportionally larger intestinal content at slaughtering time despite the same fasting period as for the other groups, a fact attributed to the smaller amount of feed ingested by these animals which induced a longer time of feed retention in the GIT. In addition, the weighing for the determination of BW was performed after a fast similar to that applied before slaughtering because $T_{3}$ animals ingested their ration rapidly, consuming no feed for 20 to $22 \mathrm{~h}$ per day.

The results of the present experiment were similar to those reported by Yamamoto et al. (2000), who observed a biological yield of 51.8 to $53.5 \%$ and a commercial yield of 43.3 to $44.1 \%$ in non-castrated Saanen kids receiving ad libitum diets and slaughtered with a fasting BW of $25 \mathrm{~kg}$. Similarly, Santos (1999) obtained a $44.3 \%$ commercial yield for Santa Inês and Bergamácia lambs with an BW of 15 to $25 \mathrm{~kg}$.

The commercial yield observed in the present study was lower than that reported by Colomer-Rocher et al. (1992) for non-castrated male kids, which was 48.3\%, ranging from 38.3 to $52.1 \%$. However, the cited authors calculated dressing out on the basis of hot carcass weight and worked with animals ranging from 5 to $115 \mathrm{~kg} \mathrm{BW}$. The biological yield obtained in the present study were higher than those reported by Ruvuna et al. (1992), who obtained $48.4 \%$ for goats 7.2 months of age.

The lack of standardization of retail cuts for goats in Brazil has led to the application of a cut system that facilitates the use of these cuts. It should be pointed out that cut standardization will be defined by the consumer market, determining minimum and maximum weights which is influenced by regional customs. In addition, the value of each cut will be the result of several factors including consumer preference, cooking application and tissue composition, with emphasis on the muscle proportion of the cut and its muscle:fat ratio.

The differences in chilled carcass weight observed between treatments were reflected on cut weight, when expressed as absolute values. However, when the proportional participation of the cuts in relation to chilled carcass weight was assessed, the cuts did not maintain the same proportions in the animals submitted to feed restriction.

The regression equations applied to chilled carcass weight and to retail cut weight as a function of feed restriction showed a linear decrease of carcass weight and retail cut weight with increasing restriction. These results were as 
Table 3 - Regression equations for retail yield and retail cuts (\%) as function of feed restriction, mean for retail yield, and means for the proportion of retail cuts in relation to the half carcass of feed-restricted kids

\begin{tabular}{|c|c|c|c|c|c|}
\hline Item & Equation & $\mathrm{R}^{2}(\%)$ & $0 \%$ restriction & $30 \%$ restriction & $60 \%$ restriction \\
\hline Retail yield ${ }^{1}$ & $\hat{\mathrm{Y}}=43.6073-0.0379 \mathrm{X} *$ & 20.02 & 43.7 & 42.4 & 40.9 \\
\hline Shoulder & $\hat{\mathrm{Y}}=20.4069+0.0075 \mathrm{X} \mathrm{ns}$ & 2.85 & 20.3 & 20.9 & 20.7 \\
\hline Neck & $\hat{\mathrm{Y}}=10.0654+0.0209 \mathrm{X} *$ & 21.56 & 10.0 & 10.7 & 11.24 \\
\hline Brisket & $\hat{\mathrm{Y}}=9.7918-0.0112 \mathrm{X} \mathrm{ns}$ & 8.07 & 9.9 & 9.2 & 9.2 \\
\hline $1^{\text {st }}-5^{\text {th }}$ rib & $\hat{\mathrm{Y}}=6.7025+0.0007 \mathrm{X} \mathrm{ns}$ & 0.09 & 6.7 & 6.8 & 6.8 \\
\hline $6^{\text {th }}-13^{\text {th }}$ rib & $\hat{\mathrm{Y}}=9.7377-0.0067 \mathrm{X} \mathrm{ns}$ & 5.08 & 9.8 & 9.4 & 9.5 \\
\hline Chump & $\hat{\mathrm{Y}}=11.6049-0.0325 \mathrm{X} * * *$ & 37.78 & 11.8 & 10.3 & 9.9 \\
\hline Leg & $\hat{\mathrm{Y}}=31.3179+0.0171 \mathrm{Xns}$ & 13.56 & 31.2 & 32.1 & 32.0 \\
\hline Leg+Shoulder+Chump & $\hat{\mathrm{Y}}=63.3297+0.0079 \mathrm{Xns}$ & 1.13 & 63.3 & 63.3 & 62.6 \\
\hline
\end{tabular}

1 Retail yield $=$ cooled carcass weight/fasting weight

$\mathrm{Y}=$ Yield or cuts as $\% ; \mathrm{X}=$ restriction level from 0 to $60 \%$.

${ }^{*} \mathrm{P}<0.05 ;{ }^{* *} \mathrm{P}<0.01 ;{ }^{* *} \mathrm{P}<0.001 ; \mathrm{ns} \mathrm{P}>0.05$

expected and reflected the difference in $\mathrm{FW}$ and $\mathrm{CCW}$ observed for the various treatments.

The regression equations of the proportion of the cuts in relation to the half carcass as a function of feed restriction (Table 3) demonstrate that the proportion of the neck increased by $0.02 \%$ and the proportion of chump decreased by $0.03 \%$ with increasing feed restriction. The percent participation of the other cuts was not affected.

The greater proportion of chump and lower proportion of neck of animals fed ad libitum may mean that the greater availability of nutrients permitted the growth of the loin, a region of later development. This agrees with the concept of centripetal growth, with progressive growth waves from the extremities to the dorsolumbar region, as mentioned by Morand-Fehr (1981) and Warmington \& Kirton (1990). In contrast, the neck, whose growth occurs earlier, is a region influenced by hormones and is characteristically developed in non-castrated males, where it acquires priority.

This behavior of growth waves and the effects observed after feed restriction suggest that a scheme of moderate nutritional restriction could be used during early kid growth, followed by improved feeding in order to take advantage of the compensatory growth and development of more valuable regions such as the loin.

The proportion of cuts in the carcass can be evaluated in a quantitative manner since the carcass should present the best possible proportion of cuts with a greater participation of edible tissues and muscle in particular. The sum of the percentages of cuts of higher commercial value, such as the leg, shoulder and loin, was not affected by feed restriction (Table 3 ) and corresponded to approximately $63 \%$ of the chilled carcass, a value similar reported by
Yamamoto et al. (2000) for Saanen kids slaughtered at a mean BW of $27 \mathrm{~kg}$.

Colomer-Rocher et al. (1992), in a study on male Saanen goats, observed that proportion of the leg was $29.4 \%$ and the proportion of the shoulder was $22.9 \%$ in carcasses weighing $10 \mathrm{~kg}$. In addition, these investigators detected a decrease in the proportion of these two cuts with increasing carcass weight ( 5 to $50 \mathrm{~kg}$ ) and an increase in the proportion of the neck from 9.3 to $13.7 \%$, probably because these were non-castrated males in which neck growth is manifested as a secondary sex trait.

The sum of the proportions of the shoulder and leg of animals fed ad libitum and of animals submitted to $30 \%$ feed restriction with carcass weight ranging from 7 to $9 \mathrm{~kg}$ showed values similar to those obtained by ColomerRocher et al. (1992) for carcasses weighing $10 \mathrm{~kg}$, in which shoulder and leg represented $52.3 \%$ of the carcass. According to Hogg et al. (1992), the leg, chump and posterior ribs (a cut similar to the $6^{\text {th }}$ to $13^{\text {th }}$ rib cut used in the present study) are cuts of higher commercial value and represent $50.9 \%$ of the carcass of castrated male Saanen kids aged 1 to 5 years. The results of the present experiment were similar if we consider the leg, chump and $6^{\text {th }}$ to $13^{\text {th }}$ rib cut for the animals of all treatments. In contrast, with respect to the shoulder, our data differed from those reported by Hogg et al. (1992), probably because these investigators included part of the neck in the cut with consequent higher absolute and proportional weights, preventing a comparison with our data.

In general, the present results suggest that the cuts of higher commercial value maintain their participation in the carcass, representing a little more than $50 \%$ of the latter 
Table 4 - Regression equations for the proportion of muscle and bone of leg as function of feed restriction and mean values for the proportion of tissues in the leg of feed-restricted kids

\begin{tabular}{|c|c|c|c|c|c|c|c|c|}
\hline Tissue & Equation & $\mathrm{R}^{2}(\%)$ & $0 \%$ & $\begin{array}{l}\text { Restriction } \\
\%\end{array}$ & $30 \%$ & $\begin{array}{l}\text { Restriction } \\
\%\end{array}$ & $60 \%$ & $\begin{array}{l}\text { Restriction } \\
\%\end{array}$ \\
\hline Muscle & $\hat{\mathrm{Y}}=70.6684-0.0211 \mathrm{X} *$ & 15.56 & & 70.7 & & 70.0 & & 69.3 \\
\hline Bone & $\hat{\mathrm{Y}}=21.5078+0.0542 \mathrm{X} * * *$ & 51.25 & & 21.5 & & 23.1 & & 25.0 \\
\hline Total fat & $\hat{\mathrm{Y}}=6.0242-0.0322 \mathrm{X} * * *$ & 38.14 & & 6.1 & & 4.9 & & 4.2 \\
\hline Subcutaneous fat ${ }^{1}$ & $\hat{\mathrm{Y}}=36.7084-0.3094 \mathrm{X} * * *$ & 59.38 & & 37.6 & & 26.5 & & 20.0 \\
\hline Intermuscular fat $^{1}$ & $\hat{\mathrm{Y}}=63.2916+0.3094 \mathrm{X} * * *$ & 59.38 & & 62.9 & & 73.5 & & 80.0 \\
\hline
\end{tabular}

$\mathrm{Y}=$ tissue $\% ; \mathrm{X}=$ restriction level from 0 to $60 \%$.

${ }^{*} \mathrm{P}<0.05 ;{ }^{* *} \mathrm{P}<0.01 ;{ }^{* * *} \mathrm{P}<0.001 ; \mathrm{ns} \mathrm{P}>0.05$.

1 Subcutaneous fat and intermuscular fat expressed as percentage of total fat

The $100 \%$ tissue composition is completed by tissues identified as "others".

when only the leg and shoulder are considered, and reaching more than $60 \%$ when the chump is added. In addition to assessing the proportion of the main cut, it is important to assess the proportion of tissues that compose them. According to Yáñez (2002), the leg of Saanen kids with an $\mathrm{BW}$ of 5 to $35 \mathrm{~kg}$ showed isogonic growth and its tissue growth curves coincided with data reported by different investigators, a fact that permits the use of leg growth curves as parameters representative of carcass behavior.

The regression equations for the proportion of leg tissues as a function of feed restriction (Table 4) show that muscles and total fat decreased by 0.02 and $0.03 \%$, respectively, with increasing restriction, while the bones increased by $0.05 \%$. The proportional participation of intramuscular fat increased by $0.31 \%$ in relation to the total amount of fat for each unit of increase in nutritional restriction, while subcutaneous fat was decreased at the same proportion.

The small, but significant, decrease in muscle percentage can be attributed to the excessive feed restriction imposed on $\mathrm{T}_{3}$ animals, which probably impaired their muscle development during the stage of greatest growth rate and highest nutritional requirements.

The data concerning relative growth, with intermuscular fat being deposited earlier than subcutaneous fat (Yáñez, 2002), together with the linear reduction of subcutaneous fat while intermuscular fat increased, indicates that, starting from a certain level of nutrient ingestion, energy is directed at deposition of subcutaneous fat. Another fact to be considered is weaning which, according to Sanz Sampelayo (1992), is when negative energy balance occurs, causing a reduction in kid body weight. However, in the present study the time elapsed between weaning and slaughtering must have been sufficient for the recovery of fat deposits, suggesting that the low proportion of subcutaneous fat observed was related to a species trait and to the physiological condition and age of the animals.

Muscle percent was 3 to $7 \%$ higher and bone and fat percent was 5 to $8 \%$ and 0.5 to $1 \%$ lower, respectively, than those observed by Colomer-Rocher et al. (1992) for the tissue composition of legs of goat carcasses weighing 5.0 to $20.0 \mathrm{~kg}$. These investigators observed that the proportion of intermuscular fat was always higher than the proportion of subcutaneous fat.

In view of the high cost and difficulty of execution, the dissection of half a carcass or cut has been replaced with the use of indirect methods to predict the tissue composition of carcasses. Two measures are usually employed for this purpose: carcass compactness, an index that estimates muscularity by the ratio between the chilled carcass and its internal length (CCW/ICL), representing an objective evaluation of conformation, and the ribeye area (REA), which is used to estimate the amount of muscle present in the carcass.

Both measurements are practical, easy to execute and widely utilized for cattle and sheep to predict the amount of muscle present in the carcasses. However, the lack of consistent information about their use in goats requires their validation with tissue composition data in order to determine their precision and reliability. Table 5 shows that there was a reduction of carcass compactness with increasing feed restriction $(\mathrm{P}<0.05)$, coinciding with the external aspect of the carcasses, which were more angular and had a smaller muscle mass in restricted animals. These results agree with the absolute values obtained for tissue composition.

Ribeye area differ between treatments $(\mathrm{P}<0.05)$ as an absolute measurement $\left(\mathrm{cm}^{2}\right)$, but these differences were not consistent when this measurement was transformed into an index, REA/HCW, in $\mathrm{cm}^{2} / \mathrm{kg}$. These results agree with those 
Table 5 - Means (+ sd) for hot carcass weight, internal carcass length, carcass compactness, and ribeye area in feed-restricted kids

\begin{tabular}{lccccc}
\hline Treatment & $\mathrm{HCW}^{1}(\mathrm{~kg})$ & Internal length $(\mathrm{cm})$ & Compactness $^{2}(\mathrm{~kg} / \mathrm{cm})$ & $\mathrm{REA}^{3}\left(\mathrm{~cm}^{2}\right)$ & $\mathrm{REA}^{2} \mathrm{HCW}{ }^{4}\left(\mathrm{~cm}^{2} / \mathrm{kg}\right)$ \\
\hline $0 \%$ restriction & $9.0 \pm 0.51 \mathrm{a}$ & $55.8 \pm 1.80 \mathrm{a}$ & $0.15 \pm 0.01 \mathrm{a}$ & $7.7 \pm 0.99 \mathrm{a}$ & $0.89 \pm 0.08 \mathrm{ab}$ \\
$30 \%$ restriction & $7.0 \pm 0.61 \mathrm{~b}$ & $51.6 \pm 1.76 \mathrm{~b}$ & $0.13 \pm 0.01 \mathrm{~b}$ & $5.3 \pm 0.76 \mathrm{~b}$ & $0.81 \pm 0.08 \mathrm{~b}$ \\
$60 \%$ restriction & $4.6 \pm 0.33 \mathrm{c}$ & $46.0 \pm 1.52 \mathrm{c}$ & $0.09 \pm 0.01 \mathrm{c}$ & $4.1 \pm 0.63 \mathrm{c}$ & $0.93 \pm 0.10 \mathrm{a}$ \\
\hline
\end{tabular}

${ }^{1} \mathrm{HCW}=$ hot carcass weight.

2 Carcass compactness = cooled carcass weight $/$ internal carcass length .

${ }^{3}$ REA = ribeye area.

${ }^{4} \mathrm{REA} / \mathrm{HCW}=$ ribeye area to hot carcass weight ratio

$a, b, c$ Means within columns with similar superscript do not differ $(P>0.05)$.

Table 6 - Regression equations for prediction of muscle amount as function of ribeye area and carcass compactness in feed-restricted kids

\begin{tabular}{lcrr}
\hline Equation & Prob. & $\mathrm{R}^{2}(\%)$ & $\mathrm{CV}$ \\
\hline$\hat{\mathrm{Y}}=99.4472+97,61535$ REA & 0.0001 & 85.20 & 10.77 \\
$\hat{\mathrm{Y}}=-222.73862+7024.4766$ COC & 0.0001 & 96.35 & 5.50 \\
\hline
\end{tabular}

$\mathrm{Y}$ : amount of leg muscle, in grams.

REA: ribeye area, in $\mathrm{cm}^{2}$.

COC: carcass compactness (cooled carcass weight/internal carcass length) in $\mathrm{kg} / \mathrm{cm}$.

obtained with leg dissection, which showed small differences in the proportion of muscles between treatments, and indicate that the development of the chump region followed that of the carcass as a whole regardless of the feeding level used. This is in agreement with the results reported by Yáñez (2002), who observed isogonic growth for the chump region in Saanen goats fed ad libitum.

To determine whether REA and/or compactness permit prediction of the amount of muscle on the leg, we performed regression analysis of the amount of muscle in the leg as a function of REA or of compactness using the data for all animals (Table 6). Is expected to be able to predict the amount of muscle on kid carcasses since the isogonic growth of the leg and the constant proportion of muscles in it permit inferring that the behavior of the leg is similar to that of the carcass as a whole within the weight range. The data showed that REA and carcass compactness permit a precise prediction of the amount of muscle of the carcass of kids growing under different nutritional conditions.

The results obtained permit us to infer that the nutritional regimen influences fat distribution since, starting from a certain level of feed ingestion, the kids directed energy towards increased deposition of subcutaneous fat, with a consequent improvement in carcass finishing and cooling process. However, for consumers this carcass is no longer lean, losing one of its best characteristics. Also, from an economic viewpoint, it should be emphasized that the cost of fat production is higher than the cost of muscle mass production.
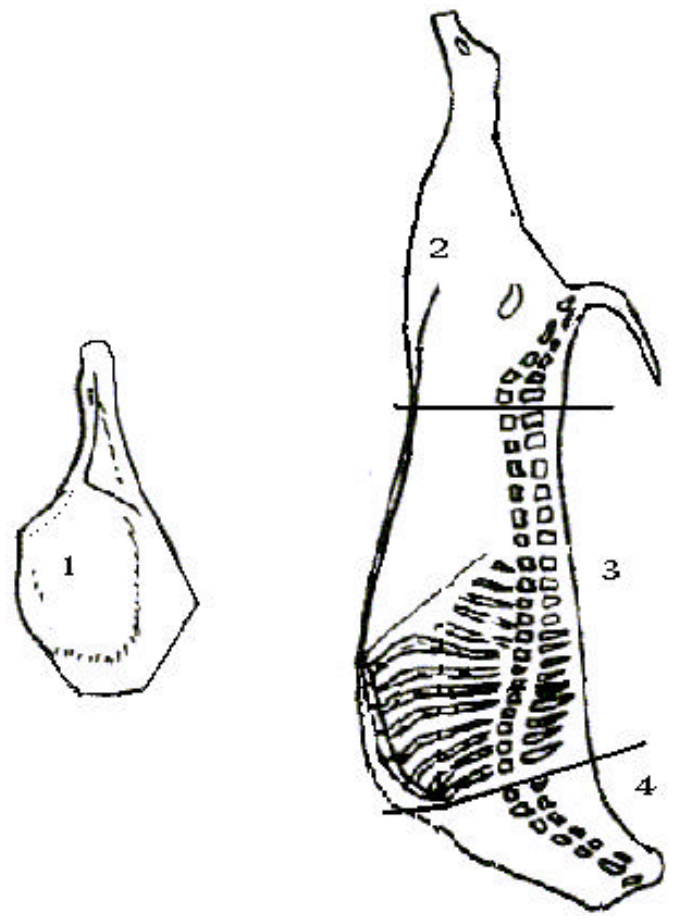

Figure 2 - Proposal of a new system of retail cuts: 1. Shoulder; 2. Leg; 3. Ribs; 4 . Neck.

The kids submitted to $30 \%$ feed restriction presented a good proportional distribution of the cuts when compared to studies on goats and sheep. However, the decision of whether or not it is convenient to restrict feeding to the level to be used should be based on the evaluation of production costs and on consumer preference.

With respect to the cuts used in the present experiment, the neck, $1^{\text {st }}$ to $5^{\text {th }} \mathrm{rib}, 6^{\text {th }}$ to $13^{\text {th }}$ rib, brisket and chump were found to weigh $0.5 \mathrm{~kg}$ or less in all treatments and were considered to be small for manipulation, commercialization and cooking. Thus, we suggest that the following cuts be obtained from carcasses weighing less than $10.0 \mathrm{~kg}$ : leg, shoulder, ribs or "rib rack", and neck (Figure 2).

\section{Conclusions}

Dairy kids submitted to moderate feed restriction present the same carcass yield and the same proportion of cuts of higher commercial value and of muscle and bone as kids fed ad libitum. Feed restriction reduces the 
quantity and modifies the distribution of adipose tissue, especially with respect to subcutaneous fat.

Moderate feed restriction may be an alternative for the reduction of production costs without affecting carcass characteristics.

\section{Literature Cited}

INSTITUTO BRASILEIRO DE GEOGRAFIA E ESTATÍSTICA IBGE [2000]. Anuário Estatístico de 1999. Disponível em: <www.ibge.gov.br.> Acesso em: 27/03/2001.

COLOMER-ROCHER, F.C.; KIRTON, A.H.; MERCER, G.J. Carcass composition of New Zealand Saanen goats slaughtered at different weights. Small Ruminant Research, v.7, p.161173,1992 .

HOGG, B.W.; MERCER, G.J.; MORTIMER, B.J. et al. Carcass and meat quality attributes of commercial goats in New Zealand. Small Ruminant Research, v.8, p.243-256, 1992.

LAWRENCE, T.L.J.; FOWLER, V.R. Growth of farm animals. CAB International, 1997. 329p

MADRUGA, M.S. Carne caprina: verdades e mitos à luz da ciência. Revista Nacional da Carne, v.23, n.264, p.34-40, 1999.

MORAND-FEHR, P. Growth. In: GALL, C. (Ed.) Goat production. London: Academic Press, 1981. p.253-283.

RUVUNA, F.; TAYLOR, J.F.; OKEYO, M. et al. Effect of breed and castration on slaughter weight and carcass composition of goat. Small Ruminant Research, v.7, p.175-183, 1992.

SANTOS, C.L. Estudo do desempenho, das características da carcaça e do crescimento alométrico de cordeiros das raças Santa Inês e Bergamácia. Lavras: Universidade Federal de Lavras, 1999. 143p. Disertação (Mestrado em Zootecnia) Universidade Federal de Lavras, 1999.
SANZ SAMPELAYO, M.R. Factores nutritivos que determinan la calidad de las canales caprinas. Análisis de su clasificación. In: JORNADAS SOBRE TECNOLOGÍA DE VALORACIÓN DE CANALES Y CARNES Y DEFENSA DE LA CALIDAD DE LOS PRODUCTOS GANADEROS - ZAFRA 92, 1992, Spain. Proceedings... Spain, 1992.

STATISTICAL ANALYSIS SYSTEM - SAS. SAS/STAT user's guide: statistics. v.8. Cary: 1999. 943p.

WARMINGTON, B.G.; KIRTON, A.H. Genetic and non-genetic influences on growth and carcass traits of goats. Small Ruminant Research, v.3, p.147-1651990.

YAMAMOTO, S.; MACEDO, F.A.; ALCALDE, C.R. et al Características de carcaça de caprinos jovens, terminados com proteína by pass. In: REUNIÃO ANUAL DA SOCIEDADE BRASILEIRA DE ZOOTECNIA, 37., 2000, Viçosa, MG. Anais... Viçosa, MG: Sociedade Brasileira de Zootecnia, 2000. p.356.

YÁÑEZ, E.A. Desenvolvimento tecidual e características da carcaça de cabritos Saanen, com diferentes pesos e níveis nutricionais. Jaboticabal: Universidade Estadual Paulista, 2002. 85p. Tese (Doutorado em Zootecnia) - Universidade Estadual Paulista, 2002.

YÁÑEZ, E.A.; FERREIRA, A.C.D.; MEDEIROS, A.N. et al. [2005]. Methodologies for ribeye area determination in goats. Small Ruminant Research. Disponível em: <http://www.science direct.com> Acesso em: 25/10/2005. 